Journal of the Society for the Study of Architecture in Canada Le Journal de la Société pour l'étude de l'architecture au Canada

\title{
Contemporary Challenges of Islamic Identity in Canada
}

Saadman Ahmed

Volume 45, numéro 2, 2020

Chercheurs en émergence

Emerging Scholars

URI : https://id.erudit.org/iderudit/1076509ar

DOI : https://doi.org/10.7202/1076509ar

Aller au sommaire du numéro

Éditeur(s)

SSAC-SEAC

ISSN

2563-8696 (numérique)

Découvrir la revue

Citer cet article

Ahmed, S. (2020). Contemporary Challenges of Islamic Identity in Canada. Journal of the Society for the Study of Architecture in Canada / Le Journal de la Société pour l'étude de l'architecture au Canada, 45(2), 4-14.

https://doi.org/10.7202/1076509ar d'utilisation que vous pouvez consulter en ligne. 


\section{PRIX 2020 MARTIN ELI WEIL}

\section{CONTEMPORARY CHALLENGES OF ISLAMIC IDENTITY IN CANADA}

SAADMAN AHMED is currently pursuing his

Master's in Architecture at the University of Waterloo (School of Architecture). Since immigrating from Bangladesh to Toronto, over ten years ago, he has been very passionate about art and culture, which eventually led him to pursue architecture as a career. He had the opportunity to travel and work in several different countries, and to be exposed to diverse styles of architecture and people from many different cultures. Having lived as both a Bengali-Muslim and a CanadianMuslim, he started to understand the depth of his own religion from a unique perspective and its influence on architecture, and therefore, he dedicated himself to study and explore the Islamic world in Canada as part of his master's research.

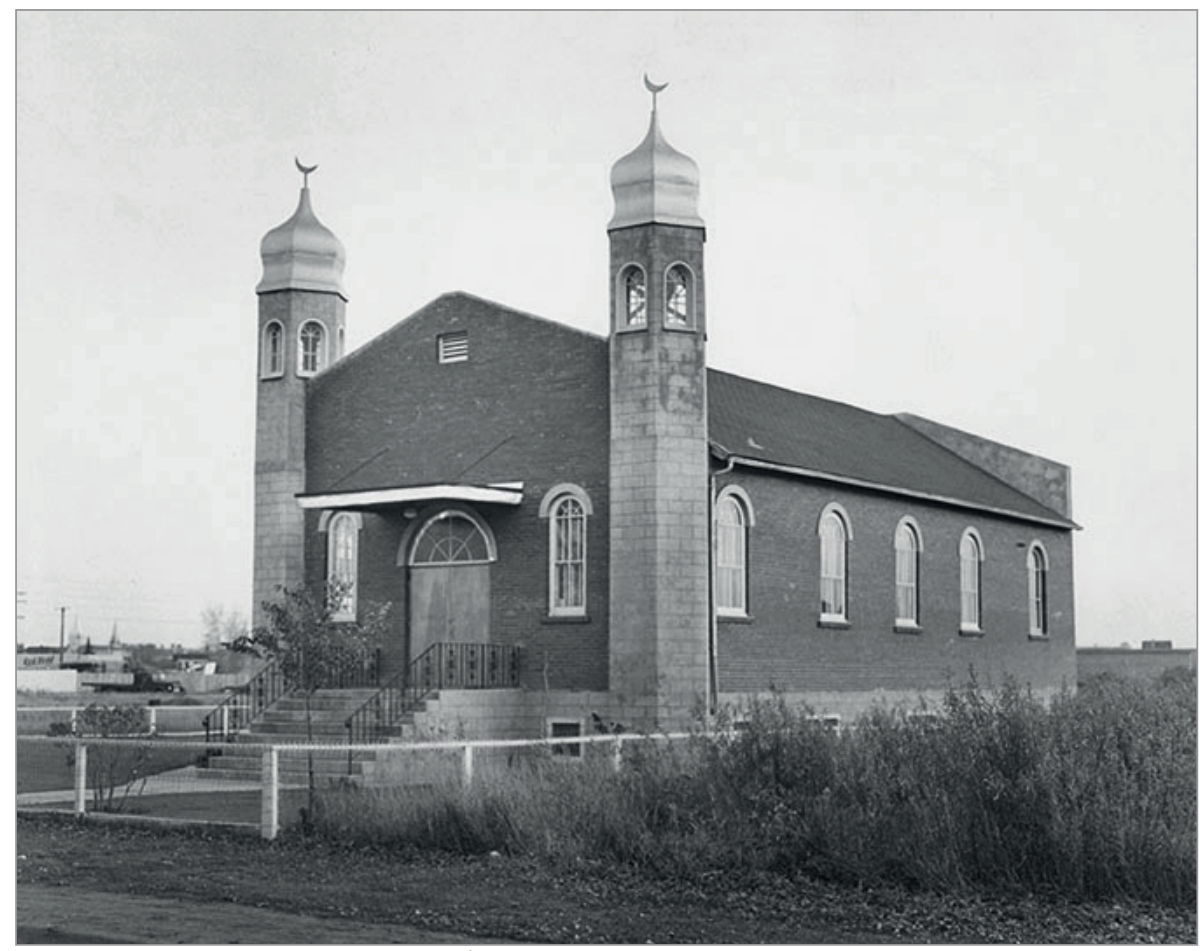

FIG. 1. AL RASHID MOSQUE, EDMONTON, 1938. | COURTESY OF AL RASHID MOSQUE, [HTTPS:I/ILLRASHIDMOSQUE.CA/OUR-STORY], ACCESSED MARCH 31, 2020.

\section{A PROBLEM OF FORM \\ AND FUNCTION}

Anew mosque would not only lead Ato traffic and noise issues but it would also lead to "rape, villainy, and destruction of Canadian values"- these were the types of claims which Mayor Bonnie Crombie of Mississauga had to fight against at a 2015 City Council meeting for a new mosque proposal. ${ }^{1}$ Several mosques in recent times have also encountered bruising opposition from the public, where cultural and political resistance are often disguised as potential increase in traffic volume and parking requirements. ${ }^{2}$ Since the early twentieth century, the mosque has been one of the most visible markers of Islam in the West. As a distinct and historic structure, the mosque is central to Muslim religious and cultural life in Canada and occupies a critical place in the practice and propagation of Islam. It has long served the Muslims as an important religious institution, a place for worship, solace, and religious instruction. Canadian mosques have also become places where Muslims can gather and engage in non-religious services and activities such as daycare, job networking, gym, and Friday school for youth. However, considering that many of these mosques exist within hostile environments, along with the economic and sociocultural struggles of the Muslim diaspora, the mosque is becoming a difficult platform for Muslims to represent their culture and religion both architecturally and socially.

Purpose-built mosques with their overtly traditional Islamic architecture 
induce angry sentiments from those who are unaccustomed to their aesthetics, historical and religious significance. Furthermore, their architectural forms attempt to directly replicate historical models, such as implementing domes, minarets and arabesque, for the sake of identity. Although meanings linked to such architectural forms evoke memories, they also have the potential to discourage architectural innovation as well as become exotic or foreign within the Canadian urban landscape. The foregoing instances of conflicts at the city council meetings are, however, not the only struggles that Muslims experience; repurposed mosques adapted in existing buildings also reflect the deprived socioeconomic realities of the current diasporic Muslim communities and they come to represent the bulk of Islamic sacred spaces in Canada. ${ }^{3}$ Repurposed mosques are properties such as former offices, grocery stores, and warehouses, that are acquired cheaply at auctions as the result of bank foreclosures or estate sales. These mosques show the ways in which immigrant Muslims must adapt and integrate their ritual and communal spaces given their underprivileged financial situation. While the growth of repurposed mosques arises from the desperate needs of Muslims for functional and cost-effective spaces, their exterior identity is camouflaged behind the façades of their former structures, and their interior spaces are chaotic and unsuitable for sacred and secular functions due to their temporal and grassroots nature. Moreover, another important underlying issue in both types of mosques is the need for reformation in the degrading social structure of the Muslim communities themselves. Movements such as the first Women's Mosque of Canada and documentary films such as Unmosqued illustrate the segregation methods used by mosque authorities to isolate Muslim women from men with physical architectural barriers. ${ }^{4}$ Muslim youth, converts, and multicultural worshippers also eschew traditional Islamic institutions, because most of the mosques are dominated by one specific ethnic group who focuses their teachings and programs toward a certain traditional culture or a particular age group-usually the elder generation. ${ }^{5}$

The objective of this essay is to examine and document how primarily contemporary mosques straddle notions of traditional architectural forms, and how the architecture of the mosque is shaped by the internal sociopolitical structure of the communities within the realities of urban, non-Islamic, and often antagonistic environments. This essay will investigate the use, interpretation, and changing nature of both purpose-built and repurposed mosques in the Greater Toronto Area (GTA). It will examine two fundamental issues revolving around the current state of the Islamic institutions: first, the growing struggle of Muslims to find a contemporary aesthetic expression for purpose-built and repurposed mosques that embody a Canadian identity-one that represents and respects the culture and built environment of Canada's urban, suburban, and natural settings; second, investigating the sociopolitical system within the Muslim communities themselves-one that dictates the increasing alienation of women, youth, and converts, in the implied and promulgated conventions of sex and ethnic segregation in mosques. This essay will also investigate specific examples of mosques in the GTA and raise key questions such as: How can a religious institution, for example the Islamic mosque, communicate its mission and values to an increasingly secular and antagonistic society? What is the value of architectural beauty and memory in purpose-built and repurposed mosques and how can it be represented in today's culture? How can architectural design encourage inclusivity instead of segregation? How can a mosque be designed to demonstrate a sense of identity and belonging?

\section{ISLAM IN CANADIAN HISTORY}

In his 2004 essay, "Islamic Architecture as a Field of Historical Enquiry," Nasser Rabbat points out that until recently, Islamic architecture has been "among the least theoretically developed areas of enquiry in the field of architecture." 6 Many of the pioneering historians, architects, artists, and draftsmen in the field were of European descent whose historical research and studies were woven into the fabric of European knowledge of Islam. ${ }^{7}$ As for Islam in Canada, very little has been documented in the history of Muslim diaspora and construction of mosques affecting the growth of urban and suburban cities and neighbourhoods. ${ }^{8}$

Established in 1938, the Al-Rashid mosque in Edmonton, $A B$, was the very first Islamic marker in Canada, serving about seven hundred Muslims in its neighbourhood. ${ }^{9}$ As the Muslim population started growing and spreading across the country, several other major cities saw the growth of both purpose-built and repurposed mosques in their urban areas, including Toronto's first mosque which was built in 1961 in a renovated storefront at 3047 Dundas Street West. Serving a small community around the neighbourhood, the storefront mosque was used by members from various cultures ranging from Pakistan, India, Bosnia, Albania, Turkey, and Egypt. Named as Mosque One by some of the early pioneers who established the institution, the members of the mosque represented a culture where diversity was tolerated, moderation was promoted, and women played a key role in fundraising, managing operations, and praying 


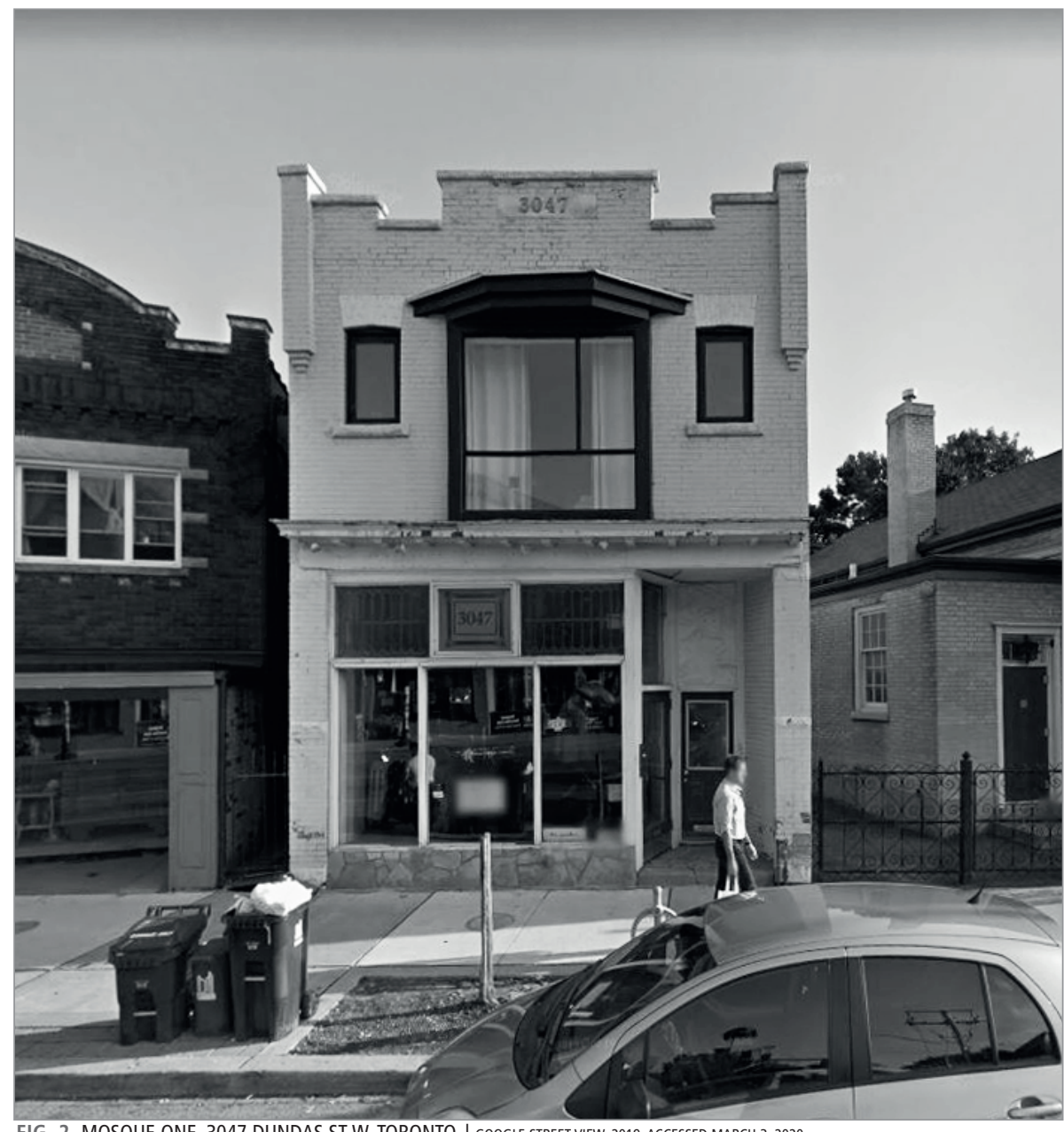

FIG. 2. MOSQUE ONE, 3047 DUNDAS ST W, TORONTO. | GOOGLE STREET VIEW, 2019, ACCESSED MARCH 3, 2020.

in the same space with the men. Besides a prayer area, the mosque included a small library and a Sunday school, designed to help children to preserve their cultural and religious identity. ${ }^{10}$

Mosque One's interior was humble but efficient. It obeyed the rules of a traditional mosque, where the carpet on the floor and the sitting arrangement of the worshippers were oriented toward the qibla wall, that is the wall facing Mecca. Being the most important wall in any mosque, the qibla is usually heavily decorated with religious ornaments and includes two important symbolic elements: the mihrab and the minbar. Originally derived from a non-religious meaning denoting a special room in a house or a throne room in a palace, the mihrab during the reign of the Caliph Uthman Ibn Affan (r. 644656) was merely an Arabic sign on the qibla wall so that pilgrims could pray in the right direction. Eventually, the mihrab evolved to be a niche on the wall with Uthman's sign placed in it, and this came to be universally understood as an architectural focal point on the wall that marks the direction to Mecca. ${ }^{11}$ The niche usually includes a minbar (either placed on the right or inside of the mihrab), which is a pulpit where the imam (prayer leader) stands to deliver sermons. The use of a minbar is especially important before and after prayers and it usually is the most heavily decorated piece of furniture in a mosque. ${ }^{12}$ Although Muslims find more liberty in constructing the interior prayer spaces to their liking, it is primarily through the exteriors of these mosques that visual distinctions from other religious institutions are evoked. However, they are more challenging to construct within the context of an urban environment in the GTA.

\section{INCOMPATIBILITY OF PURPOSE-BUILT MOSQUES}

A 2017 Angus Reid study revealed that fifty-four percent of Canadians hold an unfavorable view of Islam and only fiftysix percent would accept the construction of mosques. ${ }^{13}$ With such prejudice, it is becoming increasingly difficult and challenging for Canadian Muslims to uphold a Muslim identity. Certain exterior architectural features on purpose-built mosques become incompatible within their contexts, such as: the onion dome built on top of the prayer spaces, minarets towering over the roofs, and Arabic texts and ornaments wrapped around the façades and entrances. Although first generation Muslims feel connected to these symbolic elements of Islamic architecture, many of them have often been distilled, categorized, and repeated, either as direct replicas or in association with an identifiable "Middle-Eastern" style. Although domes and minarets perform a symbolic role in a mosque's Islamic identity, neither of these architectural forms are found universally across regions with Muslim majorities. ${ }^{14}$ Muslims simply appropriate these visual tropes to assume their "Islamicness." Moreover, this practice makes the relationship between the global and the local a recurrent tension for Muslim communities. ${ }^{15}$ Their overtly expressive forms often 


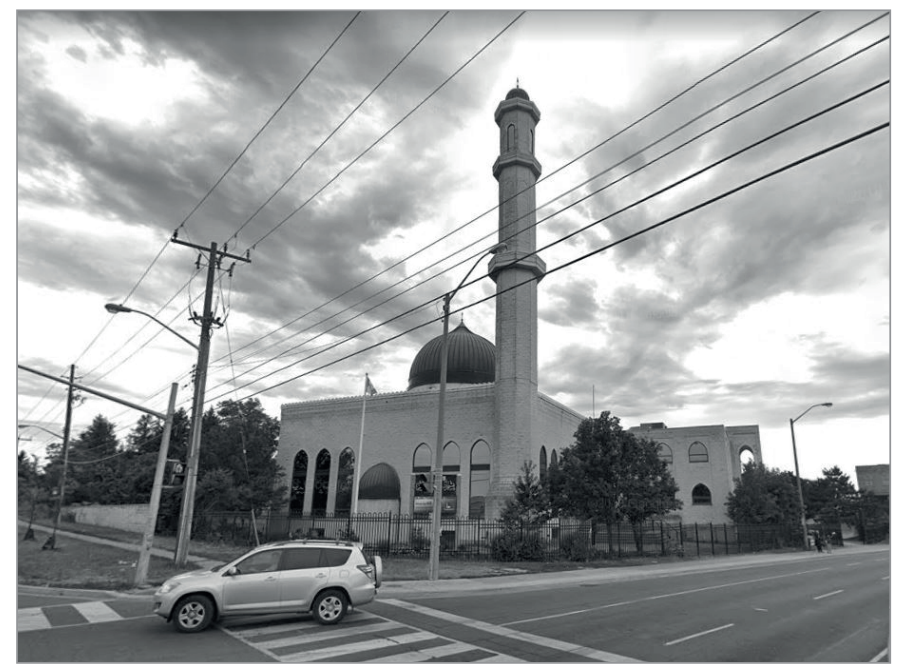

FIG. 3. NUGGET MOSQUE, 441 NUGGET AVE, SCARBOROUGH. | GOOGLE STREET VIEW, 2019, ACCESSED MARCH 15, 2020.

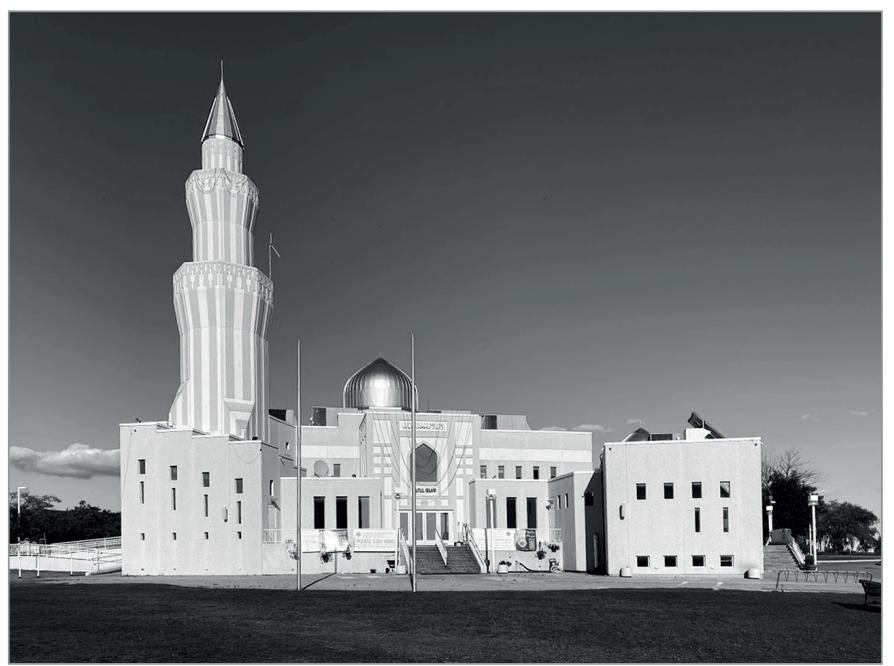

FIG. 4. BAITUL ISLAM MOSQUE, 10610 JANE ST, VAUGHAN. | SAADMAN AHMED, 2020. attract prejudice from local non-Muslim citizens. One such case occurred in 1995 in an Ontario Municipal Board meeting, when a Toronto resident representing his supporters spoke out angrily against a mosque proposal, arguing: "There is no comparison to that kind of building in Canada. It is going to be a foreign, exotic building ... If they put up this minaret and dome, it will act like a calling card for the whole community." 16 The visible character of mosques commonly attracts vandalism, such as the anti-Arabic graffiti on a York region mosque, ${ }^{17}$ urination on a Markham mosque, ${ }^{18}$ food thrown at an Owen Sound mosque, ${ }^{19}$ and countless other cases across North America. Apart from the social discrimination against Muslims, these conflicts occur due to citizens not being accustomed to the traditional Islamic architectural languages that are being created as symbolic markers for a minority group. With the expressive mosques, although immigrant Muslims essentially create an appearance which satisfies an emotional condition that has historical efficacy, some key questions must be asked as part of the discourse: How is the image of the mosque affecting the future generations of Muslims or those who do not necessarily associate with the particular memory? What is the architectural image communicated to non-Muslims? How does a mosque affect its immediate context and broader urban environment when it imitates history or an extant model?

Concurrently, "a foreign, exotic building" is also what local Muslims themselves are concerned about as the aesthetics of traditional prayer spaces are evolving to suit the needs of worshippers in an increasingly densified GTA. Mohammed Qadeer, professor emeritus of urban and regional planning at Queen's University, argues that a detail such as a minaret should not be considered a touchstone of Islamic culture, but instead he believes that, "In North America, there will be a new type of mosque... There will be other architectural solutions that harmonize the structure into the landscape."20 Others such as Nazir Khan (owner of a former warehouse Islamic Centre) and Zak Ghanim (architect of Madinah Masjid on Toronto's Danforth Avenue) agree that an Islamic prayer space only needs "a basic structure," and "a pure simple cube can perform that function." ${ }^{21}$ While many Muslim communities can trace their own cultural ancestries to the symbolic elements of traditional mosques such as domes and minarets, these elements have often been itemized, categorized, and objectified by the nineteenth-century European colonial approaches to Islamic architectural and cultural historiography in the Near East and South Asia. ${ }^{22}$ There are also practical reasons why these structures are not intrinsic or necessary for the practice or propagation of Islam. Minarets were traditionally used for elevated platforms on towers to broadcast the call to prayer, a rarity in many cities where people can use alarm clocks or smartphone apps. As for domes, they have served some temperature controlling functions in the interior; however, they are not very cost effective for underprivileged Muslim communities who are already struggling financially.

\section{GRASSROOTS ADAPTATION IN REPURPOSED MOSQUES}

Because of their experiences that purposebuilt mosques can fuel antagonistic environments, coupled with the modernist focus on function over form, Muslim 
communities have resorted to using repurposed buildings to construct their worshipping spaces. With over one hundred and twenty repurposed mosques in the GTA, diasporic Muslims use grassroots efforts to adapt their prayer spaces in available buildings that often turn out to be unsuitable to practice their sacred rituals and secular programs. The fact that many of them are concealed behind the façade of their former buildings, blending with the rest of their neighbouring postwar structures, shows that diasporic Muslims are more concerned about adjusting to their conditions than upholding an image with their mosques. Unlike their purpose-built counterpart, in which the appearance is clearly an imitation of history or an extant model, renovated mosques express their existence through kitsch aesthetic nuances. The interior of these former offices, warehouses, and storefronts are also often dark and grungy with poor spatial layouts, creating unpleasant environments for worshipping. While purpose-built mosques are blatantly expressive for the sake of distinctiveness in their architectural language, repurposed mosques remain "hidden" within the urban fabric, bearing little or no Islamic identity.

Danforth Islamic Centre, for instance, is adapted behind the ground floor storefront façade of a grocery store located in the heart of a predominantly Bengali neighbourhood in East York, ON. The big red and yellow sign indicates the name of the grocery store in the front, while a tiny washed-out sign with the name of the mosque is placed on top of the door at the centre of the storefront façade. This marks the entrance to the mosque, following a narrow flight of stairs leading the worshippers to the second-floor hallway, which is poorly lit with fluorescent lights and often filled with shoes. Two prayer spaces (for men and women) are separated into two different rooms at the end of this hallway. The floor area of the men's space being almost double that of the women's prayer space, it can accommodate more worshippers, accessible chairs, bookshelves, and larger furniture, including the minbar. In addition to the minbar, the qibla wall in the men's prayer space is filled with distractions: out-of-place notice boards, wall-mounted fans with irritating noise, bookshelves are often filled with unnecessary non-religious objects, and a difficult-to-read clock. With the five prayer times a day and Friday prayers being the busiest of them all, the prayer spaces and the elements on the wall constantly change through time. Programs such as Friday classes and lectures all take place in the prayer space, while meetings are held at a separate room adjacent to the prayer space. Divided with only a curtain from the prayer space, this meeting room can be expanded to include more worshippers if needed. The tax office and the travel agency occupying the front half of the building along with the grocery store underneath are all owned and operated by the mosque community. These commercial businesses attract Muslim customers and contribute to the economic structure of the mosque congregation, and the mosque itself holds cultural events and lectures to help retain their businesses. Although the building seeks to become a functional and temporal cultural hub for the Muslim communities, an Islamic identity, however, cannot be established through such grassroots methods of creating community programs and neither can the chaotic spaces enhance the phenomenological experience of an Islamic sacred space.

While storefront mosques, such as the Danforth Islamic Centre, are built as cost-efficient functional worshipping spaces, other repurposed mosques straddle notions of traditional Islamic symbolism in their contemporary built environment. They often resort to kitsch expressions of Islamic architecture, for instance the spray-painted entrance door of the Sheikh Deedat Centre marked with a cartoonish image of a traditional mosque (one with dome and minarets) and painted waves of a tropical beach as its background symbolizing paradise. Other mosques, such as the Fatih Mosque, literally retrofitted a miniature version of a dome and two minarets as its entrance while keeping the repurposed façade as its background. Even though the primary purpose of these mosques is to serve the immediate functional needs of the worshippers, it is nonetheless obvious that the communities yearn to represent their culture through such aesthetics and architectural tropes, whether beautiful or ugly. The debate concerning aesthetics in repurposed mosques raises several questions: Are the features and elements used by the community in the interior and exterior spaces sensible or valid? What is the motivation behind the use of various aesthetic nuances? What do these nuances mean? And how does the subjective or objective interpretation of beauty affect the outcome of a vernacular mosque design?

In terms of examining the physical characteristics of repurposed mosques and their context, we can understand that the notion of identity might not always take its shape or form in the intense symbolism of domes and minarets, but the expression can be subtle. For instance, many repurposed mosques blend in amongst halal restaurants and various cultural shops, apartment buildings, and rows of fruit markets. Arabic calligraphy and other multicultural languages can also be seen or heard spoken everywhere. Other than prayers, these spaces also include various programs such as Friday schools, 


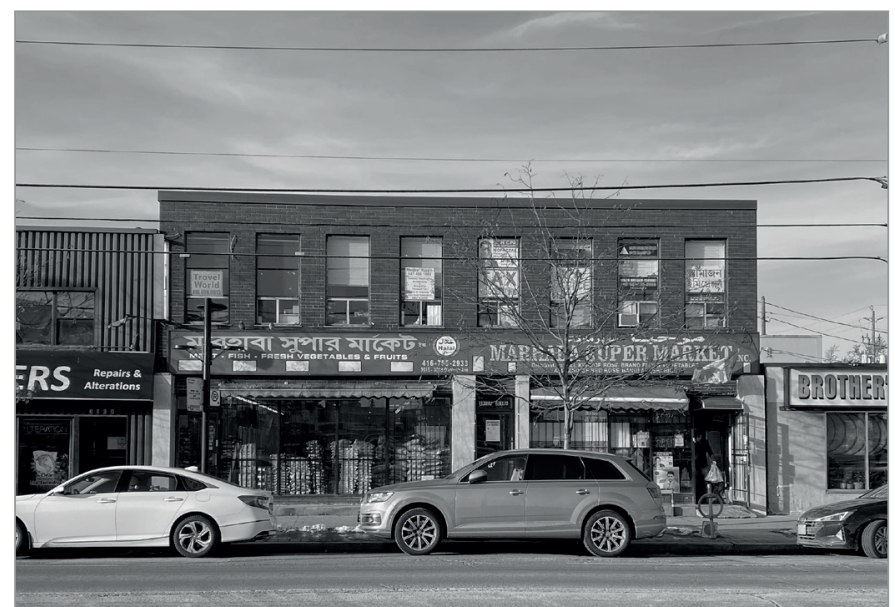

FIG. 5. DANFORTH ISLAMIC CENTRE (EXTERIOR), 3018 DANFORTH AVE, EAST YORK. | SAADMAN AHMED, 2019.

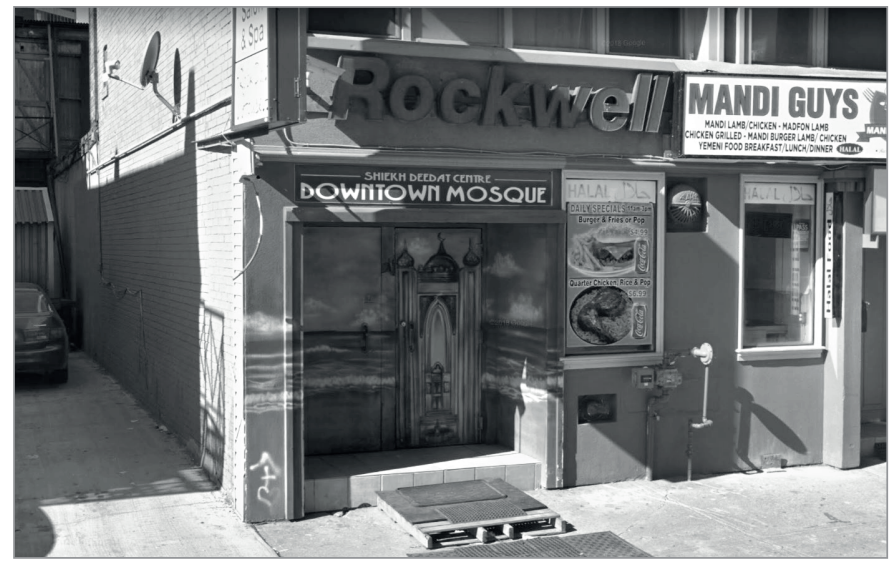

FIG. 7. SHEIKH DEEDAT CENTRE, 100 BOND ST, TORONTO. | GO0GLE STREET VIEW, 2019, ACCESSED MARCH 8, 2020.

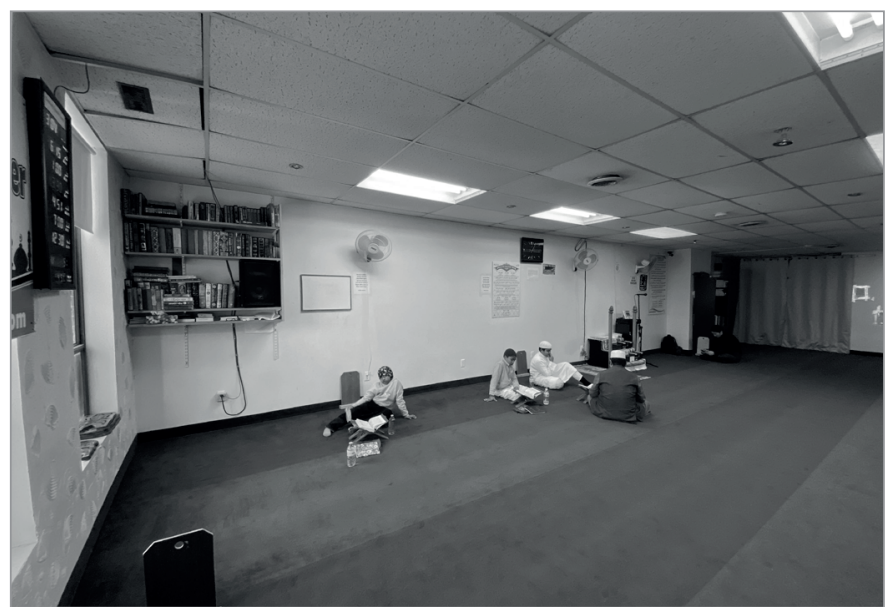

FIG. 6. DANFORTH ISLAMIC CENTRE (INTERIOR), 3018 DANFORTH AVE, EAST YORK. | SAADMAN AHMED, 2019.

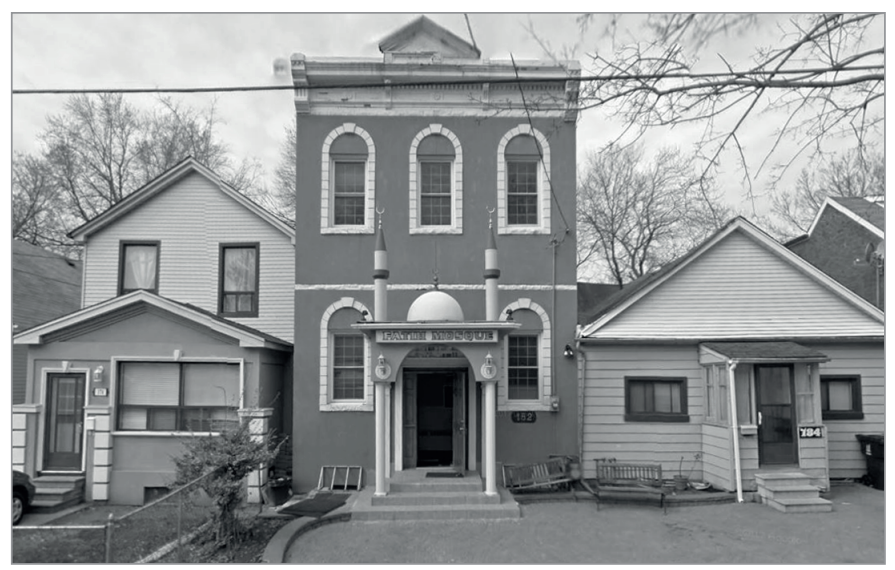

FIG. 8. FATIH MOSQUE, 182 RHODES AVE, TORONTO. | GOOGLE STREET VIEW, 2017, ACCESSED MARCH 15, 2020. religious lectures, community centres, and often become cultural hubs for various events. Although repurposed mosques do not always express their culture through design, they nonetheless use parts of the idioms and ideas of traditional Islamic architecture and values, whether programmatically or contextually. Yet, this duality of repurposed mosques raises several questions: Do the repurposed mosques simply convey "an essentialized version of mosque architecture or do they successfully claim a sense of architectural authenticity?"23 Are the subtle representations of culture behind the façades of storefronts and warehouses sufficient to uphold an Islamic identity within the diverse urban society of Canada? What is the role of design when it comes to adapting in repurposed buildings? And how can architects and the Muslim communities use architectural design as a tool for representing their culture?

\section{DEGRADING SOCIOPOLITICAL STRUCTURE}

"Muslims always seem to be talking about the injustices done to them by the outside world, but I rarely hear
Muslims talking about the unfairness that exists within our own communities," said Zarqa Nawaz in a 2005 National Film Board documentary, Me and the Mosque. ${ }^{24}$ Although many continue to push for better representation of all levels of mosque governance and participation, growing alienation within the sociopolitical system of various mosque congregations in Canada urges the need to reform. The system of segregation in both purpose-built and repurposed mosques is twofold: first, sex and gender are used to define the architecture of the mosque with Muslim women playing 
extremely limited roles in the congregations; second, from the leadership of the congregation to the symbolic elements of its architecture, almost every mosque in the GTA is built to provide for groups of people from specific culture, age, or ethnicity, and lacks the sense of a welcoming environment for youth worshippers and converts.

Physical separation of women's prayer spaces from the men's through architectural barriers such as walls, separate rooms, and even basements are a common sight in the majority of the mosques in the GTA and Canada. Nawaz added: "I have prayed in a room where there was a one-way mirror so men cannot see me. I am told we are a distraction. I look out and I see them, but they just see a mirror. Presence of women in my mosque has been erased." 25 Historically, this gender division practice emerged only in certain regions of the world. Possibly the most influential on this development was the Ottoman proliferation of a new mosque typology heavily related to the Byzantine Hagia Sophia. In addition to absorbing the use of domes and minarets, subsequent Ottoman design of mosques also included the Byzantine gynaeceum, which was a place designated for use by women. However, the gynaeceum quickly became the norm for designating gendered usage of mosque spaces and was an element that architects freely modified to suit the compositional needs regardless of the impact that it would have on the act of prayer, such as reduced areas, visibility, and access. ${ }^{26}$ Throughout the Islamic World, the norm of gendered mosque spaces spread and other methods of segregation such as walls and mezzanines were implemented by governing bodies-even in mosques that originally did not have separate spaces for men and women. However, not only does the Quran (the holy book of Islam) and authentic Sunnah (prophet's teachings) ever mention any gender or race division, but they clearly state that forbidding anyone from entering the mosque is disgraceful. It is written in the Quran that all believers have the right to go to the mosque for prayer ${ }^{27}$ and there is great punishment for those who forbid any believer to worship in the mosque. ${ }^{28}$

In the contemporary era, the desperate need for women to find inclusive places of worship produced controversial gatherings such as Canada's first Women's Mosque launching inside Trinity-St. Paul's United Church in Toronto. The mosque received major backlash from other communities with people writing comments in an online discussion (group of three hundred Toronto Muslim activists, leaders, scholars): "There is nothing in Islamic tradition to support the notion of a women only mosque" and the "effort would only divide people and reinforce harmful stereotypes about the oppression of women." ${ }^{29}$ Deeply tied to the traditional mosque environment, the co-founder of the mosque, Farheen Khan, was hoping to avoid any backlash as she simply aimed to provide an opportunity for women and girls to regularly gather for Friday prayers and together reclaim their religious inheritance. It is obvious from these events that many of these actions have directly arisen as the result of the longstanding patriarchal nature of gender segregation and leadership in mosques. In some mosques, congregants have lifted the separation barrier and afforded authoritative roles to a few Muslim women due to divergent cultural, educative, and economic shifts in the Muslim diaspora. However, these cases are rare, and the reality is that Muslim Women in the West, like many Muslim women across the globe, continue to "directly experience the consequences of oppressive misreading of religious texts." ${ }^{30}$
Women are not the only ones who suffer the consequences of segregation in the contemporary mosques. Most of the mosques in the GTA are dominated by one particular ethnic group, which includes either South Asian, Arab, or African American. As Muslims in our contemporary society become integrated within the multiracial Canadian environments, it feels increasingly uncomfortable and unwelcoming to enter a mosque that is conspicuously dominated by a certain culture. Especially for the youth of today who, growing up in a multicultural society, do not have a strong connection with their parents' country of originwhich aggravates their discomfort when entering an ethnically based space in which they feel like outsiders.

Architecturally, these types of exclusionary means do not come in the form of physical barriers but with subtle elements highlighting the social and cultural background that a mosque symbolizes. For instance, the massive dome and minaret along with the window patterns of Madinah Masjid, on Danforth Avenue, represent an Arabic aesthetics that becomes uninviting to Muslims from other cultures who do not necessarily associate with such an exotic ideal. Other mosques boast their specific culture by literally naming their institutions, for example: the Bosnian Islamic Centre of Toronto, the Afghan Canadian Islamic Community, and the Albanian Muslim Society of Toronto. The Turkish Islamic Heritage Association even implements the half-moon symbol of their flag as the point of entrance to the mosque. The programs and languages used in these mosques are also structured in a way so that they serve Muslims only from one certain ethnicity. Granted, these mosques have been formed in order to provide community and comfort to the large influx of Muslims 
that have come from diverse parts of the world to Canada, but the problem still exists; such comfort will not remain with future generations and multicultural Muslims while on Canadian soil.

As illustrated in the 2014 documentary Unmosqued, implementing these segregating notions within purpose-built and repurposed mosques has created a large amount of confusion in the minds of Millennials, Generation Xers, and women, between what is cultural practice and what is essential in Islam. ${ }^{31}$ Growing alienation has also sparked movements in which women, young people, and converts avoid traditional institutions, including multimillion-dollar mosques, in search for alternatives or "third spaces." Third spaces are different from a traditional mosque where the communities focus on inclusivity practices, including formal and informal gatherings without barriers and an authentic embrace of diversity. ${ }^{32}$ However, these spaces are rare in Canada and most of them struggle financially to expand as community centres. The phenomenon of young Muslims "unmosquing"-avoiding participation in mosques because they began to feel marginalized or alienated by their Muslim community-and the continued struggle for women in mosques raise significant questions about the roles these "minority groups within a minority group" play in religious and civic life in the West. For example, how can the Muslim community alter the physical and aesthetic makeup of mosques to include women, youth, and converts? How can programs be designed for inclusivity while respecting different cultural traditions, social practices, and gender? What are the challenges and implications of a mosque representing a contemporary Canadian culture? And how can architects and Muslim communities work together within these parameters to design a mosque for all?

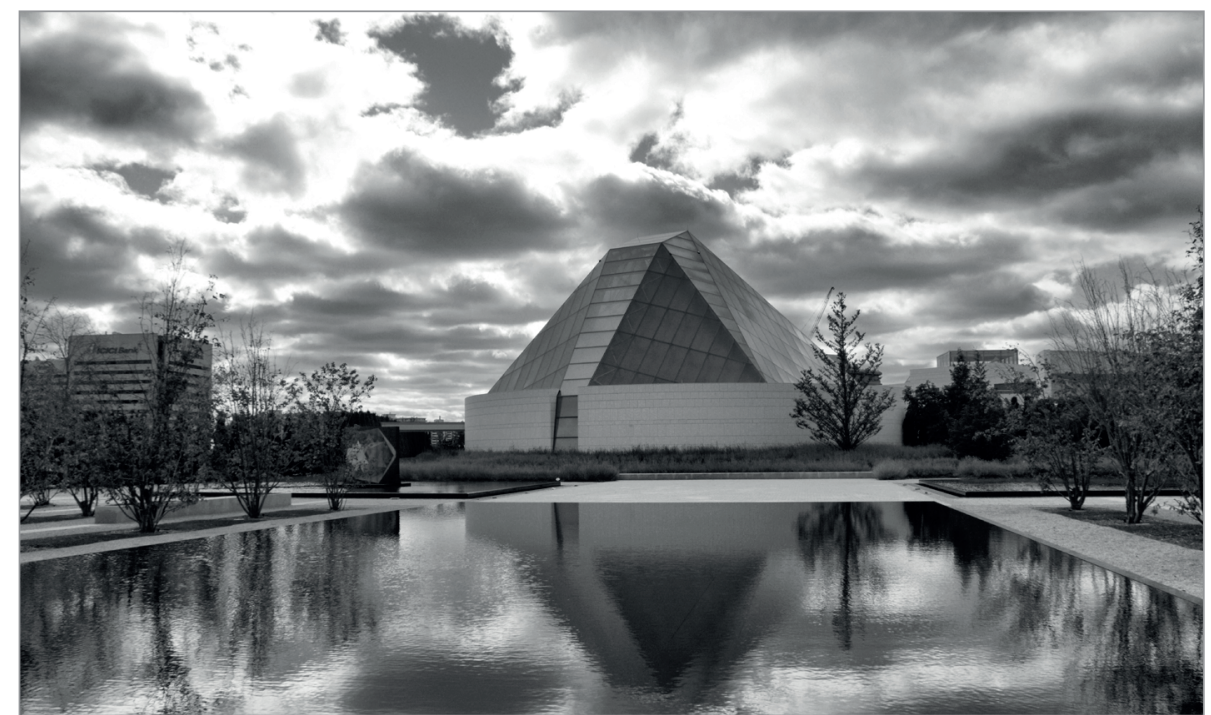

FIG. 9. ISMAILI CENTRE (EXTERIOR), 49 WYNFORD DRIVE, NORTH YORK. | BILL ONASILL, 2018, CC BY-NC-SA 2.0, WWW.FLICKR.COM, ACCESSED MARCH 31, 2020.

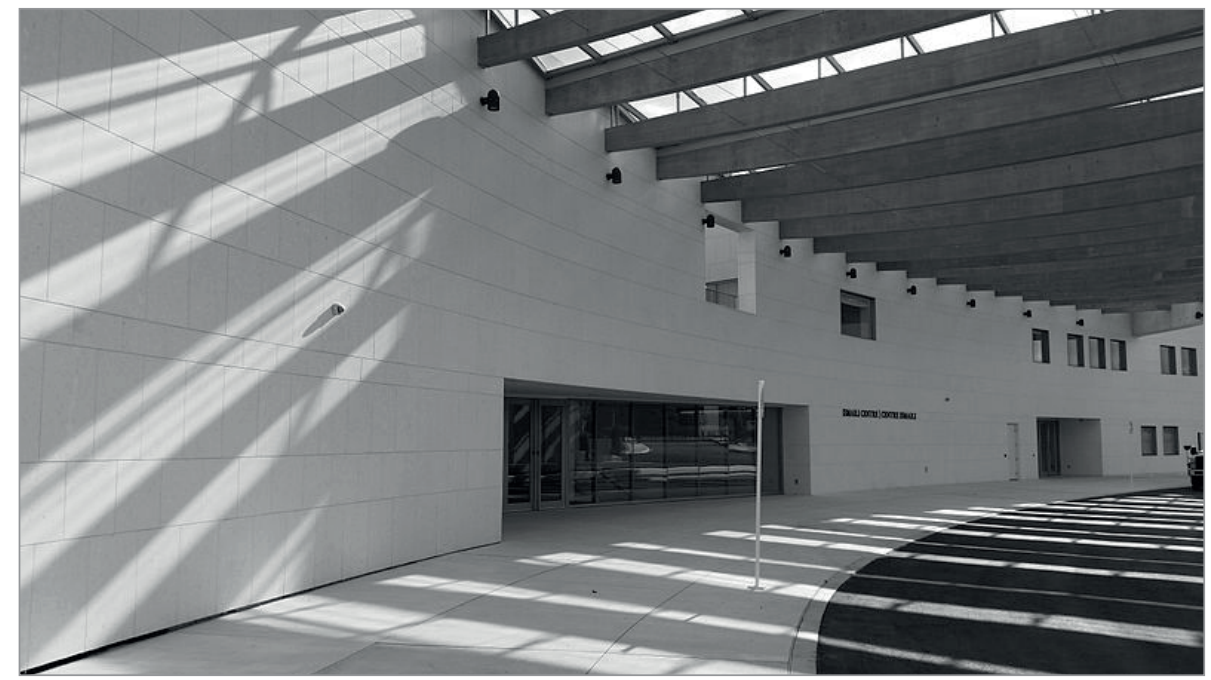

FIG. 10. ISMAILI CENTRE (ENTRANCE), 49 WYNFORD DRIVE, NORTH YORK. | JOHN OYSTON, 2014, CC BY-SA 4.0, WIKIMEDIA COMMONS, ACCESSED MARCH 31,2020

\section{RETHINKING ISLAMIC SPACE}

The first mosques of Islam, such as the house of Prophet in Medina, the Fustat, Basra, and Kufa mosques, along with the historic mosques of Canada such as Edmonton's Al Rashid Mosque and Toronto's Mosque One, can teach us the importance of cultural identity and gender inclusivity without explicit divisions or markers demarcated by architectural elements. The spaces in these mosques incorporated a type of fluidity which allowed for a singular and unified space for the community. Also learning from the few contemporary precedents existing in Canada, such as the Ismaili Centre of Toronto, Prince George Islamic Centre (Prince George, BC), or the modernist Noor Cultural Centre mosque in North 


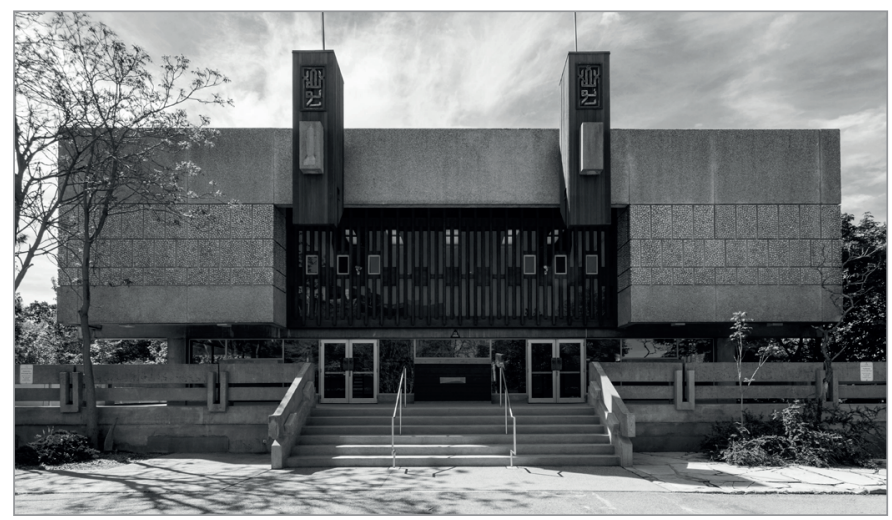

FIG. 11. NOOR CULTURAL CENTRE (EXTERIOR), 123 WYNFORD DRIVE, NORTH YORK. | THOMAS GUIGNARD, 2017, CC BY-NC-SA 2.0, WWW.FLICKR.COM, ACCESSED MARCH 20, 2020.

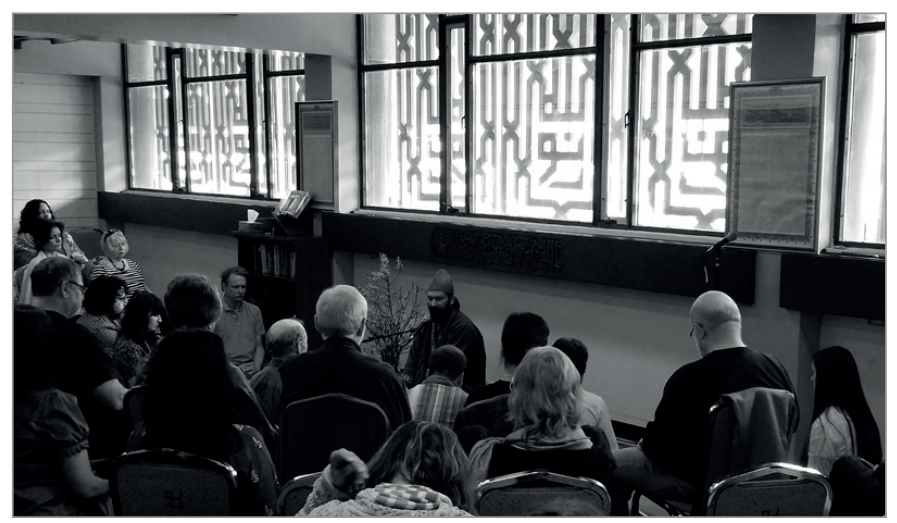

FIG. 12. NOOR CULTURAL CENTRE (INTERIOR), 123 WYNFORD DRIVE, NORTH YORK. | sol TORONTO CENTRES, 2015, CC BY-NC 2.0, WWW.FLICKR.COM, ACCESSED MARCH 31, 2020.
York, ON, we can begin to understand the need to create a Canadian identity for Muslims living and practicing their faith in Canada.

For instance, the mihrab of Prince George Islamic Centre, rather than including floral patterns like those in traditional Middle Eastern mosques, unveils the actual natural vegetation on its site by framing it with a transparent wall, thus creating a space where one can contemplate nature as a creation of God. ${ }^{33}$ The repurposed building of Noor Cultural Centre implements a shading screen composed of abstracted arabesque which lets in soft natural light to the interior prayer space. The gendered delineation in the prayer space is at its most subtle and radical, an equal horizontal division of space marked only by two separate rugs, with the space in between running perpendicular to the minimal minbar on the centre. Ismaili Centre includes a large multifaceted angular glass dome-which is a contemporary reconstruction of the symbolic eight-pointed Islamic starrising above the roof to mark the presence of the community. A sliver of glass cuts one of the faces of the dome marking the direction to Mecca and serves as the mihrab. With the diffused natural light coming through the frosted glass, the prayer space underneath the dome not only remains the most striking feature of the mosque but it is also designed to be contemplative, cultural, educational, and most importantly inclusive of all races, ages, and genders. All three mosques incorporate the contemporary use of epigraphy, geometry, and arabesque-three motifs used historically in the embellishment of mosques-in a manner which grounds the mosques appropriately to their geographic location, framing Muslim identity in a Canadian context. Such examples of mosques can be considered essential to realize that Islamic architecture can go beyond the existing norm set by Muslims, and the importance of reimagining a novel understanding of mosques in Canada.

\section{CONCLUSION}

Although they are vastly different in terms of their architectural language, arguably both purpose-built and repurposed mosques offer a complicated version of Islam-one that shows how styles and built forms influenced by and originating from a variety of Muslim cultures have taken root and flourished in Canada. ${ }^{34}$ Purpose-built mosques, in addition to reaffirming formal stylistic descriptions and grand narratives, reveal the interrelated colonial origins of their architectural histories, and as a site for showing how Islam has been "condensed into a symbolic construction with enormous psychological power." ${ }^{35}$ Conversely, repurposed mosques being unidentifiable pieces of cultural pockets within the urban fabric of the GTA, reveal the socioeconomic reality of Muslims in a North American country. As the identity exists apart from the form of the structure or appearance of the mosque, repurposed Islamic institutions emphasize the "separation of architecture's cultural content from its spiritual and community function" and arguably that "such cultural visual forms are unrelated to the spiritual or religious practice." ${ }^{36}$ In addition, the overarching problem in both of these types of mosques is the degraded sociopolitical structure within the congregations themselves-one that has had trouble addressing the concerns and interests of young Muslims, women, and other multiethnic groups.

The study of purpose-built and repurposed mosques in the GTA raises several questions regarding the parameters of Islamic architectural and Canadian history. For example, what constitutes a 
mosque outside of countries with long and historic traditions of Islam? Do either of these types of mosque buildings fit with the chronology of Islam? What are the motivations behind the uses of Islamic architectural expressions in Canada and the United States? How do mosques spatially construct gender? Do these types of mosques racialize Muslim identity, and what is at stake in such identity constructs? I would argue that architects need to be able to construct mosques that are reflective of contemporary culture and worshippers' needs while respecting Islamic traditions and memory. It is also our duty to raise awareness of the countless discriminatory and hostile situations occurring against mosques and Muslims. As Nadia Kurd argues in her doctoral dissertation,

\footnotetext{
Without an analysis of how spaces formulate and convey notions of Islam in built-form in Canada and the US, the practices and identities that are utilized by Muslim communities become further stigmatized, while their built forms are seen as being either pastiche expressions or as being incompatible with the North American architectural landscape. Or at worst, mosques in particular are seen as sites of hostility and the unknown (and for example, a potential place for the recruitment and training of extremists]. ${ }^{37}$
}

The way of life in Islam is based partly on the direct imitation of the Prophet's Sunnah and partly on the independent judgement of its followers concerning matters of personal, social, and cultural lifestyles of Muslims in various social, political, and economic contexts. Therefore, both in purpose-built mosques and in adaptive reuse of existing fabric, architects need to approach the design of the contemporary mosque in the context of Canada. While there is no simple formula, the precedents discussed suggest how an inclusive and appropriate mosque design must be "based on understanding the relationship between the eternal idea of the mosque and the needs of the present Muslim society." ${ }^{38} A$ mosque that is rooted in its time and place and one that represents all Canadian Muslims.

\section{NOTES}

1. James, Royson, 2015, "Crombie and Council Spurn Prejudice in Fight over Mississauga Mosque," The Star, October 14, [https://www. thestar.com/news/city hall/2015/10/14/crombie-and-council-spurn-prejudice-in-fight-overmississauga-mosque-james.html], accessed March 30, 2020.

2. Qadeer, Mohammad and Maghfoor Chaudhry, 2000, "The Planning System and the Development of Mosques in the Greater Toronto Area," Plan Canada, vol. 40, no. 2, p. 17.

3. Syed, Fatima, 2017, "No Minaret, No Dome. A Closer Look at the Modern Mosque," The Globe and Mail, June 5, [https://www.theglobeandmail.com/news/toronto/no-minaret-nodome-a-closer-look-at-the-modern-mosque/ article25271318/], accessed April 15, 2020. Nasser, Shanifa and Amara McLaughlin, 2017, "Protesters Outside Toronto Mosque Call for Ban on Islam as Muslims Pray Inside," $C B C$ News, February 18, [https://www.cbc.ca/ news/canada/toronto/anti-muslim-protestmasjid-toronto-1.3988906], accessed April 17, 2020.

4. Khan, Farheen, 2019, "First Women's Mosque of Canada Opens in Toronto," Now Toronto, April 24.

5. Eid, Ahmed, 2014, UnMosqued, documentary film, [www.unmosquedfilm.com/], accessed April 22, 2020.

6. Rabbat, Nasser, 2004, "Islamic Architecture as a Field of Historical Enquiry," Architectural Design, vol. 74, no. 6, p. $18-23$.

7. Id., p. 19.

8. Kurd, Nadia, 2014, Competing Visions, Common Forms: The Construction of Mosque Architecture in Canada and the US, Ph.D. dissertation, Department of Art History and Communication Studies, McGill University, Montreal.

9. Lorenz, Andrea W., 1998, "Canada's Pioneer Mosque," Saudi Aramco World, July-August, p. 28-31.
10. Bradburn, Jamie, 2015, "Historicist: Toronto's First Mosques," Torontoist, November 21, [https://torontoist.com/2015/11/historicisttorontos-first-mosques/], accessed March 30, 2020.

11. Gorlinski, Virginia, 2018, "Mihrab," Encyclopedia Britannica Inc., June 5, [https:// www.britannica.com/topic/mihrab], accessed April 22, 2020.

12. Lewis, Robert, 2017, "Minbar," Encyclopedia Britannica Inc., June 30, p. 1, [www.britannica. com/topic/minbar], accessed April 22, 2020.

13. Kurl, Shachi, 2017, "Canadians View NonChristian Religions with Uncertainty," Angus Reid Global, p. 1-8.

14. Kurd, Competing Visions, Common Forms, op. cit. p. 62.

15. Nederveen Pieterse, Jan, 1977, “Travelling Islam: Mosques without Minarets," in Oncu, Ayse and Petra Weyland (eds.), Space, Culture and Power: New identities in Globalising Cities, London and New Jersey, Zed Books Ltd., p. 177-200.

16. Engin, Isin and Myer Siemiatycki, 2002, "Making Space for Mosques: Claiming Urban Citizenship," in Sherene H. Razack (ed.), Race, Space, and the Law: Unmapping a White Settler Society, Toronto, Between the Lines, p. 185-209 at p. 205.

17. Shefa, Sheri, 2014, "Vandals Spray Anti-Arab Graffiti Outside Toronto-area Mosque," The Canadian Jewish News, November 30, [https:// www.cjnews.com/news/canada/vandalsspray-anti-arab-graffiti-outside-toronto-areamosque], accessed April 2, 2020.

18. Ngabo, Gilbert, 2020, "Vandals Recently Urinated on a Markham Mosque. Muslim Leaders Responded by Opening Their Doors to Everyone," The Star, February 25, [https:// www.thestar.com/news/gta/2020/02/25/ vandals-recently-urinated-on-this-markhammosque-muslim-leaders-responded-by-opening-their-doors-to-everyone.html/], accessed April 5, 2020.

19. Dunn, Scott, 2019, "Judge Sentencing in Mosque Vandalism Case Dec. 18," Owen Sound Sun Times, November 28, [https:// www.owensoundsuntimes.com/news/localnews/judge-sentencing-in-mosque-vandalism-case-dec-18], accessed April 22, 2020.

20. Quoted in Syed, "No Minaret, No Dome," op. cit.

21. Id. 
22. Kurd, Competing Visions, Common Forms, op. cit. p. 26.

23. Id. p. 19.

24. Nawaz, Zarqa (ed.), 2005, Me and the Mosque, Reel Diversity Competition, [https://www.nfb. ca/film/me and mosque/], accessed April 1, 2020.

25. Id.

26. Gaber, Tammy, 2015, "Gendered Mosque Spaces," Faith and Form, vol. 48, no. 1, [https://faithandform.com/feature/genderedmosque-spaces/], accessed April 22, 2020.

27. Khan, M. Muhsin and Muhamed Al-Hilali (trans.), 1999, The Qur'an. Interpretation of the Meanings in the English Language, Riyadh, Durussalam Publishers and Distributors, chapter 7, verse 29; chapter 7, verse 31.

28. Id., chapter 2 , verse 114 ; chapter 8 , verse 34 ; chapter 22, verse 25; chapter 48, verse 25 .

29. Elghawaby, Amira, 2019, "Backlash over the Women's Mosque of Canada Is Predictable and Misplaced," The Globe and Mail, May 20, [https://www.theglobeandmail.com/opinion/ article-backlash-over-the-womens-mosqueof-canada-is-predictable-and/], accessed April 15, 2020

30. Barlas, Asma, 2002, Believing Women in Islam: Unreading Patriarchal Interpretations of the Qur'an, Austin, University of Texas Press, p. 3.

31. Eid, UnMosqued, op. cit.
32. Mahmood, Faiqa, 2007, "Understanding Inclusivity Practices at 'Third Spaces,'" Institute for Social Policy and Understanding, September 17, [https://www.ispu.org/understanding-inclusivity-practices-at-third-spacesmakespace-a-case-study/], accessed April 15, 2020.

33. Gaber, Tammy, Safira Lakhani and Jessica Lam, 2017, "An Argument of Craft for Prayer - A Contemporary Mosque Design in Northern Canada," Architecture, Culture and Spirituality Symposium (ACS9), p. 1-7.

34. Rosenblatt, Naomi, 2009, "Orientalism in American Popular Culture," Penn History Review, vol. 16, no. 2, p. 53, [https:// repository.upenn.edu/cgi/viewcontent. cgi ?article $=1005 \&$ context $=$ phr], accessed April 3, 2020.

35. Moghissi, Haideh, Saeed Rahnema, and Mark J. Goodman, 2009, Diaspora by Design: Muslim Immigrants in Canada and Beyond, Toronto, University of Toronto Press, p. 13.

36. Kurd, Competing Visions, Common Forms, op. cit. p. 57.

37. Id., p. 37

38. Rasdi, Mohamad T.H.M., 2014, Rethinking the Mosque in the Modern Muslim Society, Kuala Lumpur, Institut Terjemahan and Buku Malaysia, p. 31. 